\title{
EAMR
}

European Accounting and

Management Review

EUROPEAN ACCOUNTING AND MANAGEMENT REVIEW · VOL. 2, NO. 2, 20-41 MAY 2016

\section{Determinants of customer satisfaction in call centres}

\author{
Dorina Chicu
}

Universitat Rovira i Virgili

Gerard Ryan

Universitat Rovira i Virgili

Mireia Valverde-Aparicio

Universitat Rovira i Virgili

Received October 30, 2015; accepted February 12, 2016.

\begin{abstract}
Call centres have become a central element in companies' operations, as it is the main place of communication between the companies and their customers. Given the importance of voice-to-voice encounters, the aim of this study is to explore the concept of customer satisfaction in the remote service. This paper examines the different aspects related to customer satisfaction in the specific context of the call centres that have been addressed by the existent research. The main effort was centred on extracting and connecting the different groups of determinants that are directly or indirectly linked to customer satisfaction. Findings suggest that for some reason, customer satisfaction is not among the main aims of research in the context of call centres, both in terms of number of studies and in terms of prominence of this construct within existing studies. The paper also highlights that, for call centre customer satisfaction to be understood, a multidisciplinary approach needs to be taken, including at least the functional areas of human resource management, marketing and operations management.
\end{abstract}

\section{KEYWORDS}

Call centre, remote service, customer satisfaction, determinants. 


\section{Introduction}

Most companies are increasingly extending their customer service centre beyond the traditional contact centre. Thus, the growing interest in call centres among researchers and business professionals is understandable. Since their advent, call centres have become the main contact channel between companies and customers, and at the same time, they have become a massive employment generator (Aksin et al., 2007; Russell, 2008), and industry in themselves.

However, it seems that customer satisfaction is not traditionally associated with call centre interactions or, at least, academic attention has not been devoted to this topic. Although call centres have been designed as a customer relationship management tool (CRM) in order to assist and support customers, it seems that the study of customer satisfaction in this context has not received much academic attention. Thus, the aim of this study is to explore customer satisfaction in the call centre industry and its determinants. This is an important topic because nowadays, the success of a company may depend on their call centre operations, as it is the main communication place with the consumers (Aksin et al., 2007; Anton, 1997; Cheong et al., 2008).

\section{Methodology}

In order to achieve the objective of this paper, we carried out a generic initial search in the Scopus database. The original keywords employed were "call centre" With this, we identified the international scientific literature concerning the call centre industry from 1975 to the present day, with a peak of publications in 2009. A remarkable aspect is that academic interest in call centre industry has become more static over the last five years mainly because the sector is now more consolidated.

Out of the 2517 articles identified in Scopus, 1472 are journal articles that deal directly with call centres. These cover a wide range of topics including server configuration, employee performance, job security, moral stress, and to a much lesser extent customer satisfaction. In the next phase, we narrowed down the query by combining our original search with the term "customer satisfaction". Although some of the papers included "call centre" and "customer satisfaction" as their key words, once the material was read, it became apparent that their topic was no so close to the customer satisfaction construct, so we discarded them. Finally, through search and read, we further narrowed the process 
to look for determinants of customer satisfaction in the specific context of the call centre and gathered a total of 57 papers.

\section{The call centre industry}

The existent literature has addressed the call centre realities from different perspectives. Some authors study this concept as an emergent phenomenon rather that a theoretical construct, mostly focusing on call centre classification, business models or managerial control (Russell, 2008). Meanwhile, others address the call centre as an object or analytical unit, using it as a context or unit of observation where to test some theoretical concepts (Piercy \& Rich, 2009a, 2009b; Russell, 2008).

The call centre industry has seen a significant growth over the last two decades. (Aksin et al., 2007; Feinberg et al., 2000). For instance, Feinberg, et al. (2002) state that over $70 \%$ of all customer contact takes place through call centres. The global estimation is that there are approximately 95,000 call centres employing about 7.5 million people (Holman et al., 2007). This growth has been mostly propelled by advances in information technology and the development of e-commerce (Burgers et al., 2000). The use of electronic means of payment and the deregulation of the telecommunication industry, by making transactions less expensive and at the same time more reliable, have allowed companies to broaden their horizons by offering similar products and services at lower costs. The dilemma faced in this new competitive environment is how to keep quality and satisfaction among customers while reducing costs. Thus, call centre plays an important role in companies' operations, being the main place of communication between the consumer and the provider (Aksin et al., 2007; Anton, 1997; Cheong et al., 2008). In fact, the importance of customer satisfaction in this remote context lies on managers' need to be acquainted with the determinants of customer satisfaction in order to pay attention when developing strategies by avoiding unnecessary expenses on variables that are not related.

\section{Customer satisfaction in the call centre industry}

We can infer from the literature that in general customer satisfaction may be influenced by a set of variables such as price, product performance, and service (Bitner et al., 1990; Brown and Maxwell, 2002; Day, 1984; Parasuraman et al., 1988). But how can we assess companies that offer only services? And how to keep customers satisfied if their service 
is very poor? In many cases, it is very difficult to understand, even how customer access service or what are their expectation regarding service.

In this sense, this paper examines the different aspects related to customer satisfaction in the context of call centre. From the reviewed literature we extracted and connect different groups of variables that were considered by researchers in their studies on the call centre industry, which can be classified into the following groups of determinants: managerial strategies (production line approach, customer orientation approach, off-shoring type contract); HR practices (training, salaries, job design, job discretion, team-working); HR Outcomes (employee satisfaction, burnout, turnover, absenteeism); employee behaviour (customer orientation, responsiveness, use/no use of scripts, ambidextrous behaviour); employee productivity (mainly key performance indicators); service quality (SERVQUAL metrics, and others). These sets of determinants, which have been studied by different bodies of research, but not taken into consideration altogether, are now analysed in turn.

\subsection{Service Quality}

Most studies addressing the relationship between service quality and customer satisfaction suggest a positive link between the two (Sharma et al., 2009; Upal and Dhaka, 2008). However sometimes this relationship could be moderated by an external factor such as attitude toward the service provider (Sharma, 2012; Sharma et al., 2009). This means that even if the company provides a high service quality, if the customer has a negative attitude towards the organization, satisfaction will not be achieved (Sharma et al., 2009).

In the context of the call centre, it is important to consider who assesses the service quality because managers, agents and customers have different points of view regarding service quality (Gilmore, 2001). In contrast to customer expectation, managers disregard customer orientation by using operational metrics, such as key performance indicators, in order to measure service quality (DeNuCall centre i, 2011). It depends on whether a call centre is set up in order to achieve service quality or customer satisfaction, as in many cases, it is seen as a functional tool that is used just to gain more customers into the business, or as a CRM tool in order to highlight a customer orientation approach (Kitchen and Brignell, 2004).

Therefore, interest has not so much been to address the causality between service quality and customer satisfaction, but to discern whether call centres are really looking for service 
quality or for customer satisfaction. And if so, in which cases, and how can we best address and measure service quality in this remote encounter?

In order to measure service quality, a common way among researchers is to relay on the five dimension of the SERVQUAL (Parasuraman et al., 1988). Nevertheless other alternatives should not be dismissed, such as the difference between customer expectation and customer perception of quality delivered (Upal and Dhaka, 2008) or a mix between customer orientation, SERVQUAL and performance indicators metrics (Dean, 2004). There is also some confusion regarding the use of SERVQUAL, as some authors draw on SERVQUAL metrics when attempting to measure customer satisfaction (Keiningham et al., 2006).

In any case, the five metrics of the SERVQUAL model could be split up into 2 groups: tangible and intangible metrics, which in the context of the call centre, will be represented by technology service encounter and human service encounter (reliability, responsiveness, assurance, empathy), respectively (Dean, 2008).

\subsection{Key Performance Indicators (KPI)}

From the existing literature on the call centre industry we can identify thirteen KPI: service level (call's answered within target time), average speed of answer, average time in queue, average abandonment rate, percentage of first call resolution, adherence to schedule, average talk time, after call work time, employee turnover rate, percentage of call's blocked, time before abandoning, inbound call's per agent, total call's (Feinberg et al., 2000). However, all these metrics were contemplated as internal service quality metrics in former studies (Anton, 1997). These disperse classifications cause confusion, as the line between SERVQUAL metrics and KPI metrics become blurred. Therefore, we may consider the similarities and differences among these indicators, and capture them in the most appropriate category.

In this sense, we may note that performance measurement implies a focus on individuals, groups, organizations or systems. Thus, from this large pool of indicators suggested by the literature, we have extracted three different groups:

- Employee attitude (commitment versus absenteeism): employee turnover rate; adherence to schedule;

- Employee performance: service level; average speed of answer; average talk time; average after call work time; 
- Company's system performance: abandonment rate; average time in queue, percentage of first call resolution, percentage of calls blocked, time before abandoning; inbound calls per agent; total calls.

Table 1 shows the main KPIs identified in the literature, and how we have carried out their classification into different categories.

\begin{tabular}{|c|c|c|c|}
\hline & $\begin{array}{l}\text { Key Performance } \\
\text { Indicators }\end{array}$ & Authors & KPI categories \\
\hline 1. & $\begin{array}{l}\text { Employee turnover } \\
\text { rate } \\
\text { Adherence to schedule }\end{array}$ & $\begin{array}{l}\text { (Anton, 1997; Cheong et al., } \\
\text { 2008; Feinberg et al., 2002, } \\
\text { 2000; Liu, 2010) }\end{array}$ & $\begin{array}{l}\text { Employee } \\
\text { Attitude }\end{array}$ \\
\hline 3. & Service level & \multirow{4}{*}{$\begin{array}{c}\text { (Anton, 1997; Cheong et al., } \\
\text { 2008; Feinberg et al., 2002, } \\
\text { 2000; Liu, 2010) }\end{array}$} & \multirow{4}{*}{$\begin{array}{r}\text { Employee } \\
\text { Performance }\end{array}$} \\
\hline 4. & $\begin{array}{l}\text { Average Speed of } \\
\text { Answer }\end{array}$ & & \\
\hline 5. & Average Talk Time & & \\
\hline 6. & $\begin{aligned} \text { Average } & \text { After Call } \\
\text { Work Time } & \end{aligned}$ & & \\
\hline 7. & Abandonment Rate & \multirow{4}{*}{$\begin{array}{l}\quad \text { (Abdullateef et al., 2011; } \\
\text { Aksin et al., 2007; Anton, 1997; } \\
\text { Cheong et al., 2008; Feinberg } \\
\text { et al., 2002, 2000; Liu, 2010) }\end{array}$} & \multirow{7}{*}{$\begin{array}{l}\text { Company`s } \\
\text { System } \\
\text { Performance }\end{array}$} \\
\hline 8. & $\begin{array}{l}\text { Average Time in } \\
\text { Queue }\end{array}$ & & \\
\hline 9. & $\begin{array}{l}\text { Percentage of First } \\
\text { Call Resolution }\end{array}$ & & \\
\hline 10. & $\begin{array}{l}\text { Percentage of Call } \\
\text { Blocked }\end{array}$ & & \\
\hline 11. & $\begin{array}{cc}\text { Time } & \text { Before } \\
\text { Abandoning } & \end{array}$ & $\begin{array}{l}\text { (Feinberg et al., 2002, } \\
2000 \text {; Liu, 2010) }\end{array}$ & \\
\hline 12. & $\begin{array}{l}\text { Inbound Call's per } \\
\text { Agent }\end{array}$ & & \\
\hline 13. & Total Calls & & \\
\hline
\end{tabular}

Table 1. Classification of the main KPI suggested by the literature into categories

The Employee Attitude group is going to be reviewed within the section on employee behaviour (section 4.3 below).

Considering the Employee Performance group of indicators, in general research suggests a positive link between customer satisfaction and service level (Cheong et al., 2008). However, it is not clear yet whether service level is a determinant of customer satisfaction 
or is simply a related factor. Feinberg et al. (2000) conclude that service level is one of a mix of variables that just somehow influence customer satisfaction. But this relationship could be specific only for the call centre sector, as in the banking sector no relationship has been found (Feinberg et al., 2002). So the crucial point would be to detect not how many variables are related to caller satisfaction, but which of those variables are really customer's satisfaction determinants.

In addressing the system performance group of indicators, some authors suggest that from all the variables mentioned, only first call resolution and abandonment rate could be considered as determinants caller satisfaction (Abdullateef et al., 2011; Aksin et al., 2007; Feinberg et al., 2000).

On the one hand, this implies that the customer will be dissatisfied if, for some reason, he finds himself forced to abandon the call without interacting with the agent. The reason for abandonment is still not clear, but it could be caused by the complexity of technology, busy signal, long waiting times or answering machines (Bennington et al., 2000), which are in fact part of the tangible dimension from SERVQUAL model. In this way, the waiting time may trigger satisfaction only if customers are subsequently provided with quality information and service (Garcia et al., 2012) or under a low estimation error (the difference between the perceived and actual waiting time) (Whiting and Donthu, 2009). It implies that, even if the system does not perform properly by making customers wait longer that they were expecting to, employees are still able to achieve customer satisfaction by providing quality information.

On the other hand, first call resolution, as a performance indicator, drives customer satisfaction (Abdullateef et al., 2011; Aksin et al., 2007; Feinberg et al., 2000). In other words, it implies that once customers overcome technology difficulties and get the connection with the agent, their satisfaction will depend directly on the employee adequately providing the service (Cheong et al., 2008; Garcia et al., 2012), as well as the employee's behaviour in terms of adaptiveness, responsiveness, assurance and empathy (Burgers et al., 2000; de Ruyter and Wetzels, 2000). In addition, these performances are expected to be achieved during the first contact (Abdullateef et al., 2011; Aksin et al., 2007; Feinberg et al., 2000). The problem is that in some cases, call centre jobs are designed in such a way that responsibilities are distributed among agents and in many cases employees are bound to transfer the call to another department. Consequently, customers find themselves repeatedly facing technology and paying the call's cost while waiting and listening to the answering machine. But even in this case, customer 
satisfaction still could be achieved by providing quality information and service (Garcia et al., 2012).

In other words, customers who are forced to abandon the call go on to a dissatisfaction status. However, by overcoming technology difficulties, the satisfaction would depend on employee's performance to provide quality information (Cheong et al., 2008; Garcia et al., 2012) on the first interaction with the company (Aksin et al., 2007; Feinberg et al., 2000). Hence, employees play the leading role in these actions that lead to customer satisfaction.

Therefore, we may highlight that almost all the metrics identified in the existing literature as KPI, in fact could be grouped as system performance or employee performance. Henceforth, we are going to address these variables as part of service quality or employee behaviour dimensions.

\subsection{Employee behaviour}

As employees play an important role in achieving customer satisfaction, the essential point would be to identify the determinants and outcomes of employee behaviour. In this sense, we may address two questions: how can call centre managers assure the service provided by their employees? And how can employee behaviour and attitude affect customer satisfaction?

\section{Employee-customer relationship}

As determinants of employee's performance we can highlight: employee satisfaction, suggested by the service-profit chain model (Heskett and Schlesinger, 1994); and communication, including the attentiveness, perceptiveness and responsiveness of employees (Bharadwaj and Roggeveen, 2008; de Ruyter and Wetzels, 2000). In spite of the fact that employee satisfaction is considered a determinant of both customer satisfaction and service quality (Evanschitzky et al., 2012), there is evidence that in call centres, besides the tangible dimensions, all the dimensions of the SERVQUAL model are negatively related to employee satisfaction (Ramseook-Munhurrun et al., 2010). Indeed, it seems that the excessive demand and monitoring on reaching SERVQUAL intangible metrics cause stress and emotional burnout among employees (Rod and Ashill, 2013), which ultimately is reflected as employee dissatisfaction.

It is noteworthy to highlight that throughout the call centre literature, only a few researchers address the direct link between employee satisfaction and customer 
satisfaction (Evanschitzky et al., 2012; Upal and Dhaka, 2008). In fact, Upal \& Dhaka, (2008) suggest a reciprocal correlation between employee satisfaction and customer satisfaction. It means that not only employee satisfaction and behaviour can lead to customer satisfaction, but also that customer feedback, in terms of recognition or abuse, can generate satisfaction, dissatisfaction, or emotional dissonance among employees (Litte and Dean, 2006; Poddar and Madupalli, 2012; Wegge et al., 2007). So, the relationship between customer and employee is bidirectional by nature, and depending on the interaction, satisfaction can be achieved by both parts or neither of them. This reciprocal relationship between employee and customer could be influenced by different peripheral factors, such us customer attitude toward the company or customer ethnocentrism on the one hand (Sharma, 2012; Sharma et al., 2009), and employee commitment to the organization on the other hand (Sergeant and Frenkel, 2000). As a result, the negative predisposition from one participant of the service encounter is prone to create a negative interaction between both parts. Consequently, not only customers will feel dissatisfied with employee service (Helms and Mayo, 2008). Employees, when dealing with problematic customers, will experience an emotional dissonance that lead to lower task performance (Wegge, 2006) or to turnover (Poddar and Madupalli, 2012).

\section{Employee-company relationship}

Call centres are hybrid organizations between the core activity and the hygiene/administrative activities, which frequently adopt a low-cost managerial approach (Piercy and Rich, 2009a) and at the same time provide a hybrid service between staff competence, technology usage, reliability and price (Ganguli and Sanjit, 2010)

In this context, employees are the core bridge that connects the organization and the customer. This involves many different requirements at the same time (Jasmand et al., 2012). On the one hand, in order to satisfy customers, employees are expected to provide service quality (de Ruyter and Wetzels, 2000; Upal and Dhaka, 2008). On the other hand, employees must properly use the technology and accomplish managerial requirements in terms of number of call's answered and other performance indicators (Cheong et al., 2008; Feinberg et al., 2000). This excessively demanding environment causes stress among employees. When employees control their tasks, the stress can be positive and we can say that we speak about motivation. In contrast, the loss of control over task activity, causes negative stress or emotional exhaustion, which subsequently leads to employee's turnover or absenteeism (Poddar and Madupalli, 2012). 
So, call centre's employees must be able to satisfy customers (Sergeant and Frenkel, 2000), to solve problems (Bharadwaj and Roggeveen, 2008), to deliver quality service (de Ruyter and Wetzels, 2000; Upal and Dhaka, 2008), to generate performance (Cheong et al., 2008; Feinberg et al., 2000; Piercy and Rich, 2009a, 2009b) and to engage in several activities at the same time, such as adaptive selling (Evanschitzky et al., 2012; Jasmand et al., 2012). All of this must take place in a stressful environment, dealing with problematic customers (Poddar and Madupalli, 2012; Wegge, 2006) under managerial pressures that adopt a production line approach (Gilmore, 2001) and a low-cost approach to HR practices (Wallace et al., 2000). In addition, there is some supporting evidence that call centre employees also experience work-family conflict due mainly to emotional dissonance, workload and uneasiness to deal with customer dissatisfaction (Choi, 2012). Maybe this is the reason why the call centre literature does not sufficiently address the employee satisfaction construct. Indeed, research focuses mostly on the opposite, that is, employee dissatisfaction measured in terms of employee burnout, turnover and absenteeism. As some authors suggest, it seems that employee turnover and absenteeism are the main internal problems in call centres (Piercy and Rich, 2009a) and could be solved through a different approach to HR practices.

\subsection{Human Resources Practices}

Keeping in mind the competing demands made on employees, we now turn to the HR aspects. In this sense, it should be noted that in the call centre working environment, employee behaviours and outcomes may depend on how well designed the HR practices are, since the nature of the job is so demanding that it may be up to the management of the call centre to design policies and practices in order for employees to cope and thrive in this environment. For instance, some authors propose employee commitment and ability to deliver quality service are consequences of positive HR practices (Litte and Dean, 2006), meanwhile others support that HR practices in terms of performance appraisal, employee training and open communication lead to service quality as well as to customer satisfaction (Curry and Lyon, 2008).

Notwithstanding, the existent literature suggests that in call centres both "hard" quantitative measures, as well as "soft" qualitative measures are considered in order to measure and outline employee performance (Bain et al., 2002). Thus, the adoption of sacrificial HR Practices (Wallace et al., 2000), such as task orientation and measuring the employee's productivity by "hard" quantitative measures, are drivers of negative 
outcomes, such as employee turnover or lack of commitment (Connell et al., 2009; Wallace et al., 2000).

So in order to deal with these negative outcomes, the literature suggest that HR managers must consider adopting a customer orientation approach and improve job quality (Batt and Colvin S., 2011). There are different approaches and views to the job quality metric. On the one hand, it is considered that job quality depends on external factors, such as the economic and politic regime (Holman, 2013). On the other hand job quality and job outcomes such as turnover or employee commitment, depend also on internal factors such as contract characteristics (Batt and Colvin S., 2011; Valverde et al., 2007), training programs (Piercy and Rich, 2009b; Valverde et al., 2007), teamwork (Hutchinson et al., 2000), and recruitment of emotionally ready employees (Poddar and Madupalli, 2012).

It seems that recruitment plays an important role in call centres, as hiring appropriate employees makes it possible to improve results (Dean and Rainnie, 2009). In addition, it seems that appropriate recruitment influences training in two ways. First of all, by employing referrals rather than non-referrals, we can lessen training cost as it was shown that referrals learn from their referees (Castilla, 2005). Furthermore, it seems that referrals perform better at an earlier time span compared with non-referrals (Castilla, 2005), although in the long run their performance is balanced out. It implies that we can reduce training expenditure and at the same time get better results from our workforce during the trial work period. Secondly, emotionally ready employees are more prone to deal with stressful job environments without giving up. This is a key factor in reducing turnover and absenteeism, and saves costs related to these negative outcomes. So, it is important to highlight this personal characteristic through an emotional intelligence test of candidates during the selection process (Poddar and Madupalli, 2012).

There is also evidences that employee's well-being in call centres also depends on the physical environment (McGuire and McLaren, 2009). So, even if the call centre manager recruits the right employees and ensures adequate training, it is still not enough to avoid turnover and absenteeism. Employees must be provided with a good physical environment, job security and company support. Consequently, employee well-being and commitment will be reached (Batt and Colvin, 2011).

According to (Hutchinson et al., 2000), teamwork plays an important role in the call centre job design, as it reduces turnover and absenteeism among employees and at the same time improves customer satisfaction. Effective teamwork was designed in the manufacturing context and encompasses dimensions such as group autonomy, 
decentralized problem-solving, team discretion and collective responsibility (Thompson and Wallace, 1996), but it seems that in the context of call centre this practices is not common, being substituted by teams that are designed only to facilitate staff control (van den Broek et al., 2004). The staff control and monitoring may be aligned with managerial objectives, which in the call centre environment may pose a contradiction between service quality and efficiency (Raz and Blank, 2007).

To conclude, HR managers should be able to reduce burnout, absenteeism and turnover among employees by adopting positive HR practices. They are responsible for designing the adequate workplace and tasks for employees, recruiting suitable staff, training them, and develop teamwork in order to obtain the expected performance, which should be monitored properly. This should lead to employee retention and commitment to the company by assuring job security, company support and physical environment. And all these steps should be aligned with the company managerial strategies, in light of the main aim of the call centre and the available budget.

\subsection{Managerial Strategies}

In terms of managerial approach, the literature suggests that it also plays an important role in call centre operation. We can identify two main managerial approaches: the production-line approach, which focuses on quantitative performance; and costumer orientation approach, which focuses on qualitative performance (Gilmore, 2001). In other words, call centres that adopt the production-line approach basically emphasise handling a large number of calls or focus on sales volume, and usually do not take into account the quality of the service provided or the satisfaction of customers. In this sense, in order to achieve their goals, these types of organizations try to standardize their operations by constantly pressurising and controlling their staff. On the contrary, call centres which adopt a customer-orientation approach are characterized by focusing on service quality and concern about customer satisfaction. In this sense, these types of organizations try to commit and motivate their employees by empowering and giving company support so that staff is able to provide service quality.

Although some authors report the use of both quantitative as well as qualitative metrics in order to measure call centre performance (Bain et al., 2002), there is also evidence that call centre managers still focus mostly on quantitative metrics (Gilmore, 2001), which affect negatively employees ability to deliver service quality (Dean and Rainnie, 2009). So, as we mentioned before, employees are the core part of call centre activity, as they 
directly deal with customers and at the same time use all the tools provided by the company. Thus, in order to achieve results, managers must design appropriate HR practices and leverage technology efficiently (Eric et al., 2006). But, as call centres are hybrid organizations (Piercy and Rich, 2009b), this inner management and control is sometimes determined by the type of contract between the client company and the call centre (Ren and Zhou, 2008). In other words, it means that when a call centre is outsourced, the managerial strategies depend on what type of service has been contracted, the agreed payment system and the contract design within the outsourcing centre (pay per call resolved, pay per call resolved plus share costs, partnership contract or piecemeal). For example, the piecemeal contract (the parent company pays for each call attended) may coordinate the staff level, but not the effort level. Meanwhile the "pay per call resolved" contracts (the main company pays for call resolution) compel call centre managers to design their operations in order to deliver service quality. The other two types of contracts that are suggested are: partnership contract (where the call centre is paying a user fees and also sharing a part of the costs) and pay-per-call plus share costs (where the call centre earns for every call resolution and in addition shares the cost with the main company), are considered to be the best options to achieve coordination within the supply chain, by assuring the optimal level of staff and effort within the call centre (Ren and Zhou, 2008).

Therefore, the customer orientation approach is still considered the most appropriate managerial approach if the call centre's aim is to deliver service quality and achieve customer satisfaction (Curry and Lyon, 2008; Gilmore, 2001). 


\section{Conclusion}

Considering the wide array of research contributions described above, in this section we summarise and discuss the results of this literature review with the aim of better understanding the determinants of customer satisfaction in the context of the call centre industry.

The first group of indicators, which have received most research interest, are service quality and performance indicators. Regarding service quality, the literature suggests that only human service quality can bring about customer satisfaction, as tangible dimensions lead to customer dissatisfaction. In addition, it is noteworthy that human SERVQUAL metrics influence negatively on employee satisfaction, being mediated by peripheral factors such as stress. We should note that the relationship between employee satisfaction and customer satisfaction is bidirectional and mediated by outer factors such as customer attitude toward call centre.

The second group of indicators are related to managerial strategies and HR policies. As we can see, from both groups of managerial strategies, the production line approach is directly but negatively related to employees' outcomes, such as absenteeism, turnover, commitment or ability to deliver service quality. On the other hand, managerial strategies in many cases, especially in the outsourced call centres, depend on the type of contract signed with the parent company. On the contrary, employees' positive outcomes are originated in positive HR practices. But we may highlight that these groups of indicators seem to be isolated from the core literature review on the call centre industry.

The third group of indicators refers to performance indicators, which could be grouped into system performance and employees' performance, both of them being positively related to customer satisfaction. A small number of researchers suggest that customers are dissatisfied because of rude employees and slow service, i.e. employee performance. In this study we have contributed to the literature by identifying and grouping the determinants of customer satisfaction in call centres. In order to achieve this objective, we have had to draw from scattered bodies of literature, mainly in the areas of marketing, human resource management and operations management. 
A major point to be highlighted is that the majority of studies address different concepts around customer satisfaction, but do not tend to consider its most immediate causes. That is, customer satisfaction does not tend to be the central construct or research aim in most studies carried out in this industry, both in terms of number of studies and also in terms of prominence of this construct within the existing studies. This is a significant point that should be drawn attention to by the marketing and consumer research discipline. Indeed, for decades, customer satisfaction was presented as a central issue by consumer studies, as in the traditional service encounter the main aim of a company is to satisfy customers. However, in call centres, whose whole business model centres on the idea of servicing customers, the pursuit of customer satisfaction seems to be all but elusive.

There are a number of limitations of this study that should be noted. Firstly, this literature review deals with the text of the papers considered, but does not analyse the existing data, which could have been completed by carrying out a meta-analysis. Therefore, future research should endeavour to examine and accomplish a thorough analysis of the existent call centre literature by drawing on the contributions that have been made into customer satisfaction phenomena in the specific context of remote service. Secondly, the present study does not control for differences among dispersed bodies of knowledge that address call centre industry (management, marketing, organizational behaviour, etc.), neither for differences among types of research (qualitative case studies versus quantitative studies). Thus, future research should focus on the identification and classification of these groups in order to frame the existent similarities and differences of the presented results. Finally, this study is a theoretical contribution, and thus, a natural path for this topic would be to complete it with an empirical work.

In this sense, this topic merits further research on the alternative explanations outlined above. The present study questions the precise nature of the relationship between call centres and their clients in terms of the ability or even desirability of call centres to generate customer satisfaction. This presents a number of challenging questions that could guide future studies: Is customer satisfaction a different construct altogether in call centres? Would it be useful (and would customers be able) to differentiate between the satisfaction with the specific call centre service encounter and the overall satisfaction with the company? What is the role that dissatisfaction plays? 


\section{REFERENCES}

Abdullateef, A.O., Mokhtar, S.S.M. and Yusoff, R.Z. (2011), "The mediating effects of first call resolution on call centers' performance", Journal of Database Marketing \& Customer Strategy Management, Vol. 18 No. 1, pp. 16-30.

Aksin, Z., Armony, M. and Mehrotra, V. (2007), "The Modern Call Center: A MultiDisciplinary Perspective on Operations Management Research", Production and Operations Management, Vol. 16 No. 6, pp. 665-688.

Anderson, E.W. and Sullivan, M.W. (1993), "The Antecedents and Consequences of Customer Satisfaction for Firms", Marketing Science, INFORMS: Institute for Operations Research, Vol. 12 No. 2, pp. 125-143.

Anton, J. (1997), Call Center management by the numbers, Purdue University Press, West Lafayette, Indiana, Vol. Ichor Busi.

Bain, P., Watson, A., Mulvey, G., Taylor, P. and Gall, G. (2002), "Taylorism, targets and the pursuit of quantity and quality by call centre management", New Technology Work and Employment, Vol. 17 No. 3, pp. 170-185.

Batt, R. and Colvin S., A.J. (2011), "An employment systems approach to turnover: Human resources practices, quits, dismissals, and performance", Academy of Management Journal, Vol. 54 No. 4, pp. 695-717.

Bennington, L., Cummane, J. and Conn, P. (2000), "Customer satisfaction and call centers: an Australian study", International Journal of Service Industry Management, Vol. 11 No. 2, pp. 162-173.

Bharadwaj, N. and Roggeveen, A. (2008), "The impact of offshored and outsourced call service centers on customer appraisals", Marketing Letters, Vol. 19 No. 1, pp. 13-23.

Bitner, M.J., Booms, B.H. and Tetreault, M.S. (1990), "The service encounter: Diagnosing Favorable and Unfavorable Incidents", Journal of Marketing, American Marketing Association, Vol. 54 No. 1, pp. 71-84.

van den Broek, D., Callaghan, G. and Thompson, P. (2004), "Teams without teamwork? Explaining the call centre paradox", Economic and Industrial Democracy, Vol. 25 No. 2, pp. 197-218.

Brown, G. and Maxwell, G. (2002), "Customer Service in UK call centres:: organisational perspectives and employee perceptions", Journal of Retailing and Consumer Services, Vol. 9 No. 6, pp. 309-316.

Burgers, A., Ko, de R., Keen, C. and Streukens, S. (2000), "Customer expectation dimensions of voice-to-voice service encounters: a scale-development study", International Journal of Service Industry Management, Vol. 11 No. 2, pp. 142-161.

Castilla, E.J. (2005), "Social Networks and Employee Performance in a Call Center", American Journal of Sociology, Vol. 110 No. 5, pp. 1243-1283. 
Cheong, K.J., Kim, J.J. and So, S.H. (2008), "A study of strategic call center management: Relationship between key performance indicators and customer satisfaction", European Journal of Social Sciences, Vol. 6 No. 2, pp. 268-276.

Choi, S. (2012), "Moderating effects of supervisor support, monetary rewards, and career paths on the relationship between job burnout and turnover intentions in the context of call centre", Managing Service Quality, Vol. 22 No. 5, pp. 492-516.

Churchill Jr., G.A. and Surprenant, C. (1982), "An Investigation Into the Determinants of Customer Satisfaction”, Journal of Marketing Research, Vol. 19 No. 4, pp. 491-504.

Ciavolino, E. and Dahlgaard, J.J. (2007), "ECSI - Customer satisfaction modelling and analysis: A case study", Total Quality Management and Business Excellence, Vol. 18 No. 5 , pp. 545-554.

Connell, J., Hannif, Z. and Burgess, J. (2009), “Australian Call Centres: Time to Search for a New Management Model?”, International Employment Relations Review, Vol. 15 No. 1, pp. 1-15.

Curry, A. and Lyon, W. (2008), "Call centre service quality for the public: a Scottish framework for the future", Managing Service Quality, Vol. 18 No. 2, pp. 194-208.

Day, R.L. (1984), "Modeling Choices among Alternative Responses to Dissatisfaction", Advances in Consumer Research, Association for Consumer Research, Vol. 11 No. 1, pp. 496-499.

Dean, A. (2004), "Rethinking customer expectations of service quality: are call centers different?”, Journal of Services Marketing, Vol. 18 No. 1, pp. 60-78.

Dean, A. and Rainnie, A. (2009), "Frontline employees' views on organizational factors that affect the delivery of service quality in call centers", Journal of Services Marketing, Vol. 23 No. 5, pp. 326-337.

Dean, D. (2008), "What's wrong with IVR self-service", Managing Service Quality, Vol. 18 No. 6, pp. 594-609.

DeNucci, T. (2011), "How to Put the Quality Back in Call Center Customer Service: Potentials and Pitfalls", Benefits quarterly, Vol. 27 No. 2, pp. 7-11.

Ellway, B. (2014), "The voice-to-technology (V2T) encounter and the call centre servicescape: Navigation, spatiality and movement", Journal of Service Management, Vol. 25 No. 3, pp. 349-368.

Eric, P.J., Tom, A.B. and Charles, E.M. (2006), "Operational challenges in the call center industry: a case study and resource-based framework", Managing Service Quality, Vol. 16 No. 5, pp. 477-500. 
Evanschitzky, H., Sharma, A. and Prykop, C. (2012), "The role of the sales employee in securing customer satisfaction", European Journal of Marketing, Vol. 46 No. 3, pp. 489508.

Feinberg, R., Leigh, H., Rajesh, K. and IkSuk, K. (2002), "Operational determinants of caller satisfaction in the banking/financial services call center", International Journal of Bank Marketing, Vol. 20 No. 4, pp. 174-180.

Feinberg, R.A., Kim, I.-S., Hokama, L., De Ruyter, K. and Keen, C. (2000), “Operational determinants of caller satisfaction in the call center", International Journal of Service Industry Management, Vol. 11 No. 2, pp. 131-141.

Fernie, S. and Metcalf, D.H. (1998), (Not) hanging on the telephone: payment systems in the new sweatshops, Centre for Economic Performance, London School of Economics and Political Science, London.

Frenkel, S.J., Tam, M., Korczynski, M. and Shire, K. (1998), "Beyond bureaucracy? Work organization in call centres", International Journal of Human Resource Management, Vol. 9 No. 6, pp. 957-979.

Ganguli, S. and Sanjit, K.R. (2010), "Service quality dimensions of hybrid services", Managing Service Quality, Vol. 20 No. 5, pp. 404-424.

Garcia, D., Archer, T., Ghiabi, B. and Moradi, S. (2012), "Waiting in vain: managing time and customer satisfaction at call centers", Psychology (Irvine), Vol. 3 No. 2, pp. 213-216.

Gilmore, A. (2001), "Call centre management: Is service quality a priority?", Managing Service Quality, Vol. 11 No. 3, pp. 153-159.

Gilmore, A. and Moreland, L. (2000), "Call centres: How can service quality be managed?”, Irish Marketing Review, Dublin, Vol. 13 No. 1, pp. 3-11.

Helms, M.M. and Mayo, D.T. (2008), “Assessing poor quality service: Perceptions of customer service representatives", Managing Service Quality, Vol. 18 No. 6, pp. 610622.

Heskett, J.L. and Schlesinger, L.A. et al. (1994), "Putting the Service-Profit Chain to work", Harvard Business Review, Vol. 72 No. 2, pp. 164-174.

Holman, D. (2013), "An explanation of cross-national variation in call centre job quality using institutional theory", Work, Employment and Society, Vol. 27 No. 1, pp. 21-38.

Holman, D., Batt, R. and Holtgrewe, U. (2007), The global call center report: International perspectives on management and employment, London.

Howard, J.A. and Sheth, J.N. (1969), The theory of buyer behavior, the theory of buyer behavior, John Wiley and Sons, New York. 
Huang, J., Newell, S., Poulson, B. and Galliers, R.D. (2007), "Creating value from a commodity process: A case study of a call center", Journal of Enterprise Information Management, Vol. 20 No. 4, pp. 396-413.

Hutchinson, S., Purcell, J. and Kinnie, N. (2000), "Evolving high commitment management and the experience of the RAC call centre", Human Resource Management Journal, Vol. 10 No. 1, pp. 63-78.

Jaiswal, A.K. (2008), "Customer satisfaction and service quality measurement in Indian call centres", Managing Service Quality, Vol. 18 No. 4, pp. 405-416.

Jasmand, C., Blazevic, V. and de Ruyter, K. (2012), "Generating Sales While Providing Service: A Study of Customer Service Representatives' Ambidextrous Behavior", Journal of Marketing, Vol. 76 No. 1, pp. 20-37.

Keiningham, T.L., Aksoy, L., Tor, W.A., Cooil, B. and Wahren, B.J. (2006), "Call center satisfaction and customer retention in a co-branded service context", Managing Service Quality, Vol. 16 No. 3, pp. 269-289.

Kitchen, P. and Brignell, J. (2004), "The emergence of IMC: a theoretical perspective", Journal of Advertising Research, Vol. 44 No. 1, pp. 19-30.

Levesque, T. and McDougall, G.H.G. (1996), "Customer Dissatisfaction: The Relationship Between Types of Problems and Customer Response", Canadian Journal of Administrative Sciences, Vol. 13 No. 3, pp. 264-276.

Litte, M.M. and Dean, A.M. (2006), "Links between service climate, employee commitment and employees' service quality capability", Managing Service Quality, Vol. 16 No. 5, pp. 460-476.

Liu, L.B. (2010), "Operationalizing Service Quality: Providers' Perspective", Proceedings for the Northeast Region Decision Sciences Institute, Northeast Decision Sciences Institute, pp. 533-538.

Maddern, H., Maull, R., Smart, A. and Baker, P. (2007), "Customer satisfaction and service quality in UK financial services", International Journal of Operations \& Production Management, Vol. 27 No. 9, pp. 999-1019.

Malhotra, N. and Mukherjee, A. (2004), "The relative influence of organisational commitment and job satisfaction on service quality of customer-contact employees in banking call centres", Journal of Services Marketing, Vol. 18 No. 3, pp. 162-174.

Marr, B. and Parry, S. (2004), "Performance management in call centers: lessons, pitfalls and achievements in Fujitsu Services", Measuring Business Excellence, Vol. 8 No. 4, pp. $55-62$. 
McGuire, D. and McLaren, L. (2009), "The impact of physical environment on employee commitment in call centres: The mediating role of employee well-being", Team Performance Management, Vol. 15 No. 1, pp. 35-48.

Parasuraman, A., Zeithaml, V.A. and Berry, L.L. (1988), "SERVQUAL: A Multiple-Item Scale for Measuring Consumer Perceptions of Service Quality", Journal of Retailing, Vol. 64 No. 1, pp. 12-40.

Piercy, N. and Rich, N. (2009a), "Lean transformation in the pure service environment: the case of the call service centre", International Journal of Operations \& Production Management, Vol. 29 No. 1, pp. 54-76.

Piercy, N. and Rich, N. (2009b), "High quality and low cost: the lean service centre", European Journal of Marketing, Vol. 43 No. 11, pp. 1477-1497.

Poddar, A. and Madupalli, R. (2012), "Problematic customers and turnover intentions of customer service employees", Journal of Services Marketing, Vol. 26 No. 7, pp. 551559.

Prendergast, G. and Marr, N. (1994), "Disenchantment discontinuance in the diffusion of self-service technologies in the services industry: a case study in retail banking", Journal of International Consumer Marketing.

Ramseook-Munhurrun, P., Naidoo, P. and Lukea-Bhiwajee, S. (2010), "Measuring Service Quality: Perceptions of Employees", Global Journal of Business Research, Vol. 4 No. 1, pp. 47-58.

Ravichandran, K., Mani, B.T., Kumar, S.A. and Prabhakaran, S. (2010), "Influence of Service Quality on Customer Satisfaction Application of Servqual Model", International Journal of Business \& Management, Canadian Center of Science \& Education, Vol. 5 No. 4, pp. 117-124.

Raz, A. and Blank, E. (2007), "Ambiguous professionalism: managing efficiency and service quality in an Israeli call centre", New Technology, Work and Employment, Vol. 22 No. 1, pp. 83-96.

Ren, Z.J. and Zhou, Y.-P. (2008), "Call center outsourcing: Coordinating staffing level and service quality", Management Science, Vol. 54 No. 2, pp. 369-383.

Rod, M. and Ashill, N. (2013), "The impact of call centre stressors on inbound and outbound call-centre agent burnout", Managing Service Quality, Vol. 23 No. 3, pp. 245258.

Russell, B. (2008), "Call centres: A decade of research", International Journal of Management Reviews, Vol. 10 No. 3, pp. 195-219.

de Ruyter, K. and Wetzels, M.G.M. (2000), “The Impact of Perceived Listening Behavior in Voice-to-Voice Service Encounters”, Journal of Service Research, Vol. 2 No. 3, pp. 276-284. 
Schalk, R. and van Rijckevorsel, A. (2007), "Factors influencing absenteeism and intention to leave in a call centre", New Technology, Work \& Employment, Vol. 22 No. 3, pp. 260-274.

Sergeant, A. and Frenkel, S. (2000), "When do customer contact employees satisfy customers?”, Journal of service research, Vol. 3 No. 1, pp. 18-34.

Sharma, P. (2012), "Offshore outsourcing of customer services - boon or bane?", Journal of Services Marketing, Vol. 26 No. 5, pp. 352-364.

Sharma, P., Mathur, R. and Dhawan, A. (2009), "Exploring customer reactions to offshore call centers: Toward a comprehensive conceptual framework", Journal of Services Marketing, Vol. 23 No. 5, pp. 289-300.

Thompson, P. and Wallace, T. (1996), "Redesigning production through teamworking: Case studies from the Volvo Truck Corporation", International Journal of Operations \& Production Management, Vol. 16 No. 2, pp. 103-118.

Townsend, K. (2007), "Recruitment, training and turnover: another call centre paradox", Personnel Review, Vol. 36 No. 3, pp. 476-490.

Upal, M. and Dhaka, B. (2008), "Telecommunication service gap: Call center service quality perception and satisfaction", Journal of Communications of the IBIMA, Vol. 3, pp. 18-27.

Valverde, M., Ryan, G. and Gorjup, M. (2007), "An Examination of the Quality of Jobs in the Call Center Industry", International Advances in Economic Research, Vol. 13 No. 2, pp. 146-156.

Wallace, C.M., Eagleson, G. and Waldersee, R. (2000), "The sacrificial HR strategy in call centers", International Journal of Service Industry Management, Vol. 11 No. 2, pp. $174-184$.

Wegge, J. (2006), "Work motivation, organisational identification, and well-being in call centre work", Work and Stress, Vol. 20 No. 1, pp. 60-83.

Wegge, J., Vogt, J. and Wecking, C. (2007), "Customer-induced stress in call centre work: A comparison of audio- And videoconference", Journal of Occupational and Organizational Psychology, Vol. 80 No. 4, pp. 693-712.

Whiting, A. and Donthu, N. (2009), "Closing the gap between perceived and actual waiting times in a call center: results from a field study", Journal of Services Marketing, Vol. 23 No. 5, pp. 279-288.

Wood, S., Holman, D. and Stride, C. (2006), "Human resource management and performance in UK call centres", British Journal of Industrial Relations, Vol. 44 No. 1, pp. 99-124. 
Zeithaml, V.A., Berry, L.L. and Parasuraman, A. (1993), "The nature and determinants of customer expectations of service", Journal of the Academy of Marketing Science, Vol. 21 No. 1, pp. 1-12. 